\title{
Investigation of subsequent and co-infections associated with SARS-CoV-2 (COVID-19) in hospitalized patients
}

\author{
Matthew P. Crotty ${ }^{1}$; Ronda Akins ${ }^{2}$; An Nguyen ${ }^{2}$; Rania Slika ${ }^{3}$; Kristen Rahmanzadeh ${ }^{1}$; Marie H. \\ Wilson $^{4}$; Edward A. Dominguez ${ }^{5}$ \\ ${ }^{1}$ Department of Pharmacy, Methodist Dallas Medical Center, Dallas, Texas, USA \\ ${ }^{2}$ Department of Pharmacy, Methodist Charlton Medical Center, Dallas, Texas, USA \\ ${ }^{3}$ Department of Pharmacy, Methodist Mansfield Medical Center, Dallas, Texas, USA \\ ${ }^{4}$ Infection Prevention and Control, Methodist Dallas Medical Center, Dallas, Texas, USA \\ ${ }^{5}$ Organ Transplant Infectious Diseases, Methodist Transplant Specialists, Methodist Dallas Medical \\ Center, Dallas, Texas, USA
}

\section{Correspondence to:}

Matthew Crotty, Department of Pharmacy, Methodist Dallas Medical Center, Dallas, Texas, USA. Email: matthewcrotty@MHD.com, tel: 214-963-7252

\begin{abstract}
Background: SARS-CoV-2 has drastically affected healthcare globally and causes COVID-19, a disease that is associated with substantial morbidity and mortality. We aim to describe rates and pathogens involved in co-infection or subsequent infections and their impact on clinical outcomes among hospitalized patients with COVID-19.

Methods: Incidence of and pathogens associated with co-infections, or subsequent infections, were analyzed in a multicenter observational cohort. Clinical outcomes were compared between patients with a bacterial respiratory co-infection (BRC) and those without. A multivariable Cox regression analysis was performed evaluating survival.

Results: A total of 289 patients were included, $48(16.6 \%)$ had any co-infection and $25(8.7 \%)$ had a BRC. No significant differences in comorbidities were observed between patients with co-infection and those without. Compared to those without, patients with a BRC had significantly higher white blood cell counts, lactate dehydrogenase, C-reactive protein, procalcitonin and interleukin-6 levels. ICU admission ( 84.0 vs $31.8 \%$ ), mechanical ventilation ( 72.0 vs $23.9 \%$ ) and in-hospital mortality (45.0 vs $9.8 \%$ ) were more common in patients with BRC compared to those without a co-infection. In Cox proportional hazards regression, following adjustment for age, ICU admission, mechanical ventilation, corticosteroid administration, and pre-existing comorbidities, patients with BRC had an increased risk for in-hospital mortality (adjusted HR, 3.37; 95\% CI, 1.39 to 8.16; $\mathrm{P}=0.007$ ). Subsequent infections were uncommon, with 21 infections occurring in $16(5.5 \%)$ patients.

Conclusions: Co-infections are uncommon among hospitalized patients with COVID-19, however, when BRC occurs it is associated with worse clinical outcomes including higher mortality.
\end{abstract}

Keywords: COVID-2019, SARS-CoV-2, Co-infection, subsequent infection, clinical outcomes

Competing Interests: All authors have completed the ICMJE uniform disclosure form at www.icmje.org/coi_disclosure.pdf and declare: no support from any organization for the submitted work; MPC has received honorariums from Nabriva Therapeutics, Theravance Biopharma, Inc., Paratek Pharmaceuticals, and bioMerieux, Inc., outside the submitted work; EAD reports being a sub-investigator for clinical trials through Gilead, research funding from Nektar, personal fees for delivering educational presentations for Sanofi-Pasteur, and has received honorariums from Cumberland Pharmaceuticals and Tetraphase Pharmaceuticals, outside the submitted work; no other authors report relationships or activities that could appear to have influenced the submitted work. 
medRxiv preprint doi: https://doi.org/10.1101/2020.05.29.20117176; this version posted June 2, 2020. The copyright holder for this preprint (which was not certified by peer review) is the author/funder, who has granted medRxiv a license to display the preprint in perpetuity. It is made available under a CC-BY-NC-ND 4.0 International license .

\section{Background}

SARS-CoV-2 is a pandemic coronavirus that has drastically affected healthcare globally and causes COVID-19, a disease that is associated with substantial morbidity and mortality. [1-4] COVID-19 is predominantly a respiratory disease and frequently causes pneumonia. [1-4]

Co-infections have been described between other respiratory viruses and bacterial pathogens, sometimes leading to worse clinical outcomes. [두, $\underline{6}$ ] Early reports suggest that coinfections between SARS-CoV-2 and other respiratory pathogens (both viral and bacterial) occur at varying rates and with an unknown impact on clinical outcomes. [7] In contrast, empiric antibiotic use has been reported among most patients, including broad spectrum agents and those with potential toxicities. $[\underline{1}, \underline{8}, \underline{9}]$ Moreover, patients with COVID-19 frequently have prolonged hospitalizations (including intensive care unit [ICU] stays) and often require mechanical ventilation and other invasive procedures that put them at a high risk for nosocomial infections. $[1-3]$

Among currently available descriptions of co-infections in patients with COVID-19, most are lacking details related to diagnostic work-up, critical illness, time to infection detection, pathogens identified, and clinical outcomes. [7] A more detailed description and evaluation of co-processes may allow for a better understanding of the disease process and patient prognosis, as well as inform improved antimicrobial stewardship practices. We sought to describe rates and pathogens involved in co-infection or subsequent infections and their impact on clinical outcomes among hospitalized patients with COVID-19.

\section{Methods}

\section{Study Population and Data Collection}

The Aspire institutional review board approved this multicenter observational cohort study as minimal-risk research using data collected for routine clinical practice and waived the requirement for informed consent. Patients age 18 years or older admitted to any of the 4 acute care hospitals within Methodist Health System in Dallas, Texas, USA between March 1, 2020, and April 30, 2020 were eligible for inclusion. All consecutive patients who were sufficiently medically ill to require hospital admission with confirmed SARS-CoV-2 infection by positive result on reverse-transcriptase-polymerase-chain-reaction (RT-PCR) testing of a nasopharyngeal sample during the index admission or in the emergency department prior to admission were included. Patients were excluded if either they only received care in the emergency department 
medRxiv preprint doi: https://doi.org/10.1101/2020.05.29.20117176; this version posted June 2, 2020. The copyright holder for this preprint (which was not certified by peer review) is the author/funder, who has granted medRxiv a license to display the preprint in perpetuity. It is made available under a CC-BY-NC-ND 4.0 International license .

or they were admitted to inpatient/observation status for less than 24 hours. Clinical outcomes were monitored until May 14, 2020, the final date of follow-up. All data were collected from the electronic health record (Epic; Verona, Wisconsin; www.epic.com).

Data collected included patient demographic information, comorbidities, initial laboratory tests, diagnoses during the hospital course, inpatient medications, treatments (including invasive mechanical ventilation), and outcomes (including length of stay, discharge, and mortality). Demographics, baseline comorbidities, and presenting clinical studies were available for all admitted patients. All clinical outcomes are presented for patients who completed their hospital course at study end (discharged alive or dead). Clinical outcomes available for those in hospital at the study end point are presented, including invasive mechanical ventilation, ICU care, and length of stay in hospital. Outcomes such as discharge disposition and readmission were not available for patients in hospital at study end because they had not completed their hospital course. Initial laboratory testing was defined as the first test results available, typically within 24 hours of admission. For initial laboratory testing and clinical studies for which not all patients had values, percentages of total patients with completed tests are reported.

\section{Outcome Measures and Study Definitions}

Respiratory co-infection was defined as collection of a respiratory culture, blood culture, or respiratory diagnostic (Streptococcus pneumoniae urine antigen, Legionella spp. urine antigen, or respiratory viral panel) positive for a respiratory pathogen within 72 hours of positive SARS-CoV-2 RT-PCR test collection. Respiratory co-infection was considered to have occurred if respiratory flora was grown from a respiratory culture and the patient was treated with systemic antibiotics. Other co-infection was defined as collection of a non-respiratory culture, positive for a non-respiratory pathogen within 72 hours of positive SARS-CoV-2 RT-PCR test collection. Subsequent infections were defined as those with collection of culture or diagnostic more than 72 hours after a positive SARS-CoV-2 RT-PCR test collection.

\section{Microbiologic and Laboratory Diagnostics}

Patients with COVID-19 were identified via RT-PCR tests with Federal Drug Administration (FDA) Emergency Use Authorization (EUA) for detecting SARS-CoV-2 nucleic acid. RT-PCR samples were collected from nasopharyngeal and lower respiratory specimens. All 
medRxiv preprint doi: https://doi.org/10.1101/2020.05.29.20117176; this version posted June 2, 2020. The copyright holder for this preprint (which was not certified by peer review) is the author/funder, who has granted medRxiv a license to display the preprint in perpetuity. It is made available under a CC-BY-NC-ND 4.0 International license .

diagnostic tests were performed according to the manufacturer's package inserts. Influenza screening testing was performed using the BD Veritor System (BD Diagnostics, Sparks, MD). Molecular tests using the Verigene Respiratory Pathogens, Gram-Positive, and Gram-Negative Blood Culture nucleic acid tests (Nanosphere, Northbrook, IL, USA) were performed on nasopharyngeal samples and positive blood cultures, respectively. Nasopharyngeal screening for MRSA was done for patients receiving anti-MRSA antibiotic treatment utilizing Spectra MRSA (Thermo Fisher Scientific, Lenexa, KS, USA). Urine antigen testing for S. pneumoniae and Legionella spp. were performed using BinaxNow (Alere, Scarborough, ME). All testing for CDI was performed using the Illumigene molecular assay (Meridian Bioscience, Inc., Taunton, MA). All bacterial pathogens were identified via MicroScan WalkAway (Beckman Coulter, Inc., Brea, CA).

\section{Statistical Analysis}

Descriptive analyses were performed for all variables. Mean \pm standard deviation were determined for normally distributed variables and median and interquartile range were determined for non-normally distributed continuous variables. Count and proportions are presented for all categorical variables.

Bivariate comparisons using Chi-squared (or Fisher's exact) tests were conducted for nominal data and two sample t-test or Mann-Whitney $U$ test for continuous data (depending on normality distribution) were used to compare characteristics and outcomes between the sample of patients.

A Cox proportional hazards model was fit for time to death, controlling for treatment group and potential confounders (age in years, intensive care unit admission, mechanical ventilation, chronic obstructive pulmonary disease, coronary artery disease, chronic kidney disease, cirrhosis) based on a priori plausibility, bivariate associations within our data, and ruling out multicollinearity using variance inflation factors with values of less than 3 considered acceptable.

Significance was evaluated at $\alpha=.05$ and all testing was 2 -sided. Because of the potential for type I error due to multiple comparisons, findings for analyses of secondary end points should be interpreted as exploratory. All statistical analyses were performed using SPSS software (IBM SPSS Statistics, version 22.0; Chicago, IL, USA). 
medRxiv preprint doi: https://doi.org/10.1101/2020.05.29.20117176; this version posted June 2, 2020. The copyright holder for this preprint (which was not certified by peer review) is the author/funder, who has granted medRxiv a license to display the preprint in perpetuity. It is made available under a CC-BY-NC-ND 4.0 International license .

\section{$\underline{\text { Results }}$}

A total of 417 patients were screened with 289 patients ultimately included; 128 patients were excluded due to having an admission stay of less than 24 hours, with most being discharged from the emergency department. Among included patients, 48 (16.6\%) had any co-infection (25 bacterial respiratory infections, $8.7 \%)$ compared to $241(83.4 \%)$ without co-infection (Figure 1).

Patient characteristics are described in Table 1. Mean age of included patients was 58.6 (SD +/-14.4) years and most had chest imaging consistent with pneumonia $(86.1 \%)$. Additionally, most patients had at least one underlying comorbidity (81.7\%) with diabetes $(46.4 \%)$ and hypertension $(61.6 \%)$ being the most common. No significant differences in comorbidities were observed between patients with a bacterial respiratory co-infection (BRC) and those without. Few patients were immunocompromised overall (10.3\%) with no BRC patients found to have a history of transplant, active malignancy, or HIV. Among admission laboratory values assessed, median white blood cell count (WBC) was higher among patients with a BRC compared to those without $\left(10.1 \mathrm{vs} 7.0 \times 10^{9} / \mathrm{L}, \mathrm{P}=0.002\right)$. Additionally, several other median laboratory values were higher among patients with a BRC compared to those without: lactate dehydrogenase (1210 vs $834, \mathrm{P}=0.008)$, C-reactive protein (182 vs $74, \mathrm{P}=0.013)$, procalcitonin ( 0.37 vs $0.07, \mathrm{P}=0.001$ ), and interleukin-6 (48 vs $10, \mathrm{P}=0.011$ ). Procalcitonin (PCT) greater than or equal to 0.25 had a sensitivity of $73.9 \%$ and a specificity of $65.2 \%$ for BRC. Whereas, at a PCT value greater than or equal to 0.5 , sensitivity and a specificity were $43.5 \%$ and $81.3 \%$, respectively.

Some therapies targeting COVID-19 were more commonly administered to patients with a BRC compared to those without including systemic corticosteroids (48 vs $22 \%, \mathrm{P}=0.004$ ), and tocilizumab (20 vs $4.9 \%, \mathrm{P}=0.013$ ). In contrast, patients without a $\mathrm{BRC}$ received remdesivir more often $(10.6 \%$ vs $0, \mathrm{P}=<0.001)$. There were no observed differences in rates of administration of hydroxychloroquine. Antibiotics were given to most patients (93.8\%) with no differences between groups observed.

Blood cultures were obtained from most patients overall $(242 / 289,83.7 \%)$ and were commonly obtained among patients with a BRC compared to those without (100 vs 82.2\%, $\mathrm{P}=0.019$ ) (Table 2). Other microbiologic diagnostics were also more frequently completed in patients with a BRC compared to those without including: influenza testing (96 vs 72\%), Streptococcus pneumoniae urine antigen testing (80 vs 52.7\%), MRSA nasopharyngeal screening 
medRxiv preprint doi: https://doi.org/10.1101/2020.05.29.20117176; this version posted June 2, 2020. The copyright holder for this preprint (which was not certified by peer review) is the author/funder, who has granted medRxiv a license to display the preprint in perpetuity. It is made available under a CC-BY-NC-ND 4.0 International license .

(48 vs 22.3\%), and respiratory cultures (64 vs 14.8\%). Conversely, Legionella urine antigen and C. difficile testing were similar amongst groups.

Among patients with a respiratory co-infection, $25(91.4 \%)$ had a bacterial pathogen and $6(8.6 \%)$ had a respiratory virus other than SARS-CoV-2 (Table 3). Among bacterial pathogens, respiratory flora was most commonly identified $(\mathrm{n}=15,60 \%)$ followed by Staphylococcus aureus $(\mathrm{n}=5,20 \%)$ and S. pneumoniae $(\mathrm{n}=3,12 \%)$. Of the S. aureus isolates, $3 / 5(60 \%)$ were methicillin-resistant. No predominant respiratory virus was identified as causing co-infection. As co-infection rates were low, few positive microbiologic diagnostics were observed overall. Of note, only 3/159 (1.8\%) of S. pneumoniae urine antigens, 0/ 28 Legionella urine antigens, 7/197 (3.6\%) of respiratory viral panels, and 1/71 (1.4\%) nasopharyngeal MRSA screens performed were positive.

Hospital outcomes are presented in Table 1, noting $25(8.7 \%)$ patients were still hospitalized at the time of final analysis. ICU admission was common overall (36.3\%) and occurred more in patients with a BRC compared to those without (84 vs $31.8 \%, \mathrm{P}=<0.001$ ). Moreover, patients with a BRC were more likely to be mechanically ventilated (72 vs $23.9 \%$, $\mathrm{P}=<0.001)$ compared to those without. In-hospital mortality was higher among patients with a BRC compared to those without in an unadjusted bivariate analysis (45 vs $9.8 \% ; \mathrm{P}=<0.001$ ). Among subgroup of patients admitted to the ICU, in-hospital mortality remained higher in the group with a BRC $(9 / 16,56.3 \%)$ compared to those without $(20 / 66,30.3 \% ; \mathrm{P}=0.051)$. No differences in ICU admission, mechanical ventilation, or in-hospital mortality was observed for patients with a non-respiratory co-infection or those with a viral respiratory co-infection compared to the non-BRC group as a whole.

In a Cox proportional hazards regression, following adjustment for age, ICU admission, mechanical ventilation, corticosteroid administration, and pre-existing comorbidities, patients with a BRC had an increased risk for in-hospital mortality (adjusted HR, 3.37; 95\% CI, 1.39 to 8.16; $\mathrm{P}=0.007$ ) (Figure 2, Table 4).

A total of 21 subsequent infections occurred in $16(5.5 \%)$ of patients; respiratory infections were most common $(n=12,57.1 \%)$ followed by bloodstream infections $(n=3,14.3 \%)$ and $C$. difficile infections $(\mathrm{n}=3,14.3 \%)$ (Table 3). Time from admission to subsequent infection ranged from 5 to 23 days (median of 11 days). Patients that received systemic corticosteroids were more likely to develop a subsequent infection $(11 / 70,15.7 \%)$ during hospitalization than 
medRxiv preprint doi: https://doi.org/10.1101/2020.05.29.20117176; this version posted June 2, 2020. The copyright holder for this preprint (which was not certified by peer review) is the author/funder, who has granted medRxiv a license to display the preprint in perpetuity. It is made available under a CC-BY-NC-ND 4.0 International license .

those that $\operatorname{did}$ not $(5 / 219,2.3 \% ; \mathrm{P}=<0.001)$. Moreover, patients that received systemic corticosteroids were more likely to develop a subsequent respiratory infection $(7 / 70,10 \%)$ compared to those that did not $(4 / 219,1.8 \% ; \mathrm{P}=0.002)$. Each of the 3 patients with subsequent fungal infections had received systemic corticosteroids. Similar to corticosteroids, patients that received tocilizumab were more likely to have a subsequent infection $(5 / 18,27.8 \%)$ than those that did not $(11 / 271,4.1 \% ; \mathrm{P}=0.001)$.

\section{Conclusions}

Among hospitalized patients with COVID-19, co-infections occurred in only $16.6 \%$ of patients. Moreover, respiratory co-infections with bacterial $(8.7 \%)$ or viral $(2.1 \%)$ pathogens were infrequent and no predominant pathogens were identified. For non-BRC (sources other than respiratory) or viral co-infections, there was no increased morbidity or mortality observed. When BRC did occur they were associated with higher rates of ICU admission, mechanical ventilation, and in-hospital mortality. Following adjustment for age, ICU admission, mechanical ventilation, corticosteroid administration, and pre-existing comorbidities, patients with a BRC had an increased risk for in-hospital mortality (adjusted HR, 3.37; 95\% CI, 1.39 to 8.16; $\mathrm{P}=0.007$ ). Subsequent infections occurred in $5.5 \%(n=16)$ patients, with onset ranging from 5 to 23 days after admission (median 11 days). Subsequent infections were most commonly of respiratory source $(57.1 \%)$ followed by bloodstream and CDI (14.3\% each). Patients that received either corticosteroids or tocilizumab were more likely to have developed a subsequent infection.

Unlike previous observations with other respiratory viruses causing pneumonia, SARSCoV-2 does not appear to have high rates of co-infection with either bacterial or other viral pathogens.[10] This contrast may be attributable to the widespread prevalence of the disease and presentation to the hospital with the disease in patients normally considered immunocompetent compared to other respiratory viruses. Several case reports have demonstrated that co-infections with respiratory viruses, including influenza, and SARS-CoV-2 do occur.[ㄱ, 11-21] Recently an evaluation of 5,700 hospitalized patients with COVID-19 in the New York City area similarly showed only 42 of 1996 patients tested $(2.1 \%)$ with another respiratory virus identified on admission.[8] One analysis of patients presenting to an emergency department showed that 24 of $116(20.7 \%)$ patients with COVID-19 had a viral co-infection detected, however, only 1 of the 24 was admitted to the hospital.[15] It is possible that there is some disparity between rates of 
medRxiv preprint doi: https://doi.org/10.1101/2020.05.29.20117176; this version posted June 2, 2020. The copyright holder for this preprint (which was not certified by peer review) is the author/funder, who has granted medRxiv a license to display the preprint in perpetuity. It is made available under a CC-BY-NC-ND 4.0 International license .

viral co-infection among patients seen in the inpatient and outpatient settings as such patients are likely to vary in age and comorbidities. Moreover, respiratory viruses are notably seasonal and the timing of our evaluation (influenza activity was declining by the time of first SARS-CoV-2 detection) and others is therefore notable as it relates to viral co-infections with the potential for variance to occur depending on circulating respiratory viruses. Bacterial co-infection was also infrequently identified with SARS-CoV-2 in this study cohort.

The low rates of bacterial co-infections identified are noteworthy as they contrast sharply with antibiotic exposures observed. Rawson and colleagues conducted a review of the early data related to bacterial and fungal co-infections with SARS-CoV-2 and found that $72 \%$ of patients with COVID-19 received systemic antibacterials yet only 62 of $806(8 \%)$ had an identified bacterial or fungal co-infection. We similarly found high rates of antibacterial administration among hospitalized patients with COVID-19 (93.8\% of patients) and low rates of bacterial coinfection (14.5\% with any bacterial co-infection and $8.6 \%$ with respiratory co-infection). Although BRC rates with SARS-CoV-2 are seemingly lower than those reported with influenza (ranging from 11 to $35 \%$ in most reports),[22] increased morbidity and mortality is still of concern. Previously, associations between BRC related to 2009 pandemic influenza and higher rates of mechanical ventilation and mortality have been described.[5] We similarly observed higher rates of mechanical ventilation and in-hospital mortality among patients with BRC. Synergistic interactions between bacterial pathogens such as S. pneumoniae have been described and the pathophysiologic mechanisms could also hold true for SARS-CoV-2.[ㅌ, 23, 24]

To our knowledge, there is currently no specific antimicrobial stewardship interventions related to COVID-19 reported. A meta-analysis evaluating the ability for procalcitonin to distinguish viral from bacterial pneumonia demonstrated sensitivity and specificity of serum procalcitonin were 0.55 and 0.76 , respectively.[25] This performance likely varies to some degree on patient setting, [26, 27] but is fairly consistent with our findings for procalcitonin and BRC (sensitivity of $73.9 \%$ and specificity of $65.2 \%$ at a cut-off value of $0.25 \mathrm{ng} / \mathrm{mL}$ ). Utilization of procalcitonin could prove helpful in decreasing unnecessary and potentially harmful antibiotic utilization in treating hospitalized COVID-19 patients and warrants further investigation.

Diagnostic tests needed to effectively evaluate hospitalized COVID-19 patients for coinfection could also play a substantial role in optimizing management. Schimmel et al. reported on utilization of $S$. pneumoniae urinary antigen utilization among 159, 894 hospital admissions 
medRxiv preprint doi: https://doi.org/10.1101/2020.05.29.20117176; this version posted June 2, 2020. The copyright holder for this preprint (which was not certified by peer review) is the author/funder, who has granted medRxiv a license to display the preprint in perpetuity. It is made available under a CC-BY-NC-ND 4.0 International license .

for community-acquired pneumonia in the U.S. and determined that less than $20 \%$ of admissions had the test performed.[28] Moreover, there appeared to be opportunity for positive tests to lead to reductions in broad-spectrum antibiotic use. More than half $(55 \%)$ of patients in the current study had a $S$. pneumoniae urine antigen performed, but only 3 resulted positive. This test could have helpful implications related to personal protective equipment (PPE) and exposure minimization, but the low yield of the test should be balanced with its potential impact.

Several limitations of this study should be recognized. First, the evaluation was conducted at 4 hospitals within the same healthcare system in Dallas, Texas, USA during the first two months in which the SARS-CoV-2 pandemic was recognized in the area and application to other geographic areas or time periods may not apply. Specifically, the seasonality of other respiratory viruses may alter rates of co-infection observed and continued observations over time, notably in Fall and Winter months, may help in delineating seasonal trends. Second, the decision to consider patients with only respiratory flora as having a BRC could be considered a limitation in interpreting the association of BRC on clinical outcomes among patients with COVID-19. However, when analyses excluding these patients were done, rates of ICU admission, mechanical ventilation, and in-hospital mortality remained higher among patients with a BRC suggesting that these patients are similar to those with more obvious BRC (e.g., $S$. pneumoniae). Moreover, respiratory flora and disruption of the lung microbiome are increasingly recognized as potential causes of pneumonia and could explain the "missing" pathogens frequently observed.[29-32] Molecular diagnostic tests for respiratory specimen could also prove fruitful in increasing yield of pneumonia pathogens, but were not available during this study. Third, PPE restrictions to minimize healthcare exposure may impact obtainment and/or quality or frequency of respiratory cultures or other diagnostics; thus potentially influencing the rates of co-infection identified. Fourth, it is difficult to separate the impact of BRC and other factors such as COVID-19 severity or underlying disease states on clinical outcomes. Therefore, the findings of worse clinical outcomes among patients with BRC and COVID-19 should be strictly seen as hypothesis generating. Additionally, we did not address the potential efficacy of antibiotic therapy herein, leaving it unknown what the impact of antibiotic therapy on patients with BRC would be. Finally, 25 patients remained hospitalized at the time of follow-up completion and it is unknown how rates or types of subsequent infections in this study might be affected if longer follow-up was possible among this group. 
medRxiv preprint doi: https://doi.org/10.1101/2020.05.29.20117176; this version posted June 2, 2020. The copyright holder for this preprint (which was not certified by peer review) is the author/funder, who has granted medRxiv a license to display the preprint in perpetuity. It is made available under a CC-BY-NC-ND 4.0 International license .

Co-infections with SARS-CoV-2 are uncommon among hospitalized patients; however, $\mathrm{BRC}$ is associated with worse clinical outcomes including higher mortality when it does occur. Future evaluations on antibiotic therapy and antimicrobial stewardship are warranted to determine how to minimize use of unnecessary antimicrobials while still optimizing therapy among patients with co-infections. Additionally, evaluations of necessary diagnostic work-up among hospitalized COVID-19 patients could assist clinicians in decision-making and minimize exposure to this highly contagious virus. SARS-CoV-2 and COVID-19 are likely to remain a primary cause of hospitalization in the coming months to years and an increased understanding of the disease-state continuum and its management is needed to improve clinical outcomes associated with this severe illness.

\section{References}

1. Goyal P, Choi JJ, Pinheiro LC, et al. Clinical Characteristics of Covid-19 in New York City. N Engl J Med 2020.

2. Zhou F, Yu T, Du R, et al. Clinical course and risk factors for mortality of adult inpatients with COVID-19 in Wuhan, China: a retrospective cohort study. Lancet 2020; 395(10229): 1054-62.

3. Zhu N, Zhang D, Wang W, et al. A Novel Coronavirus from Patients with Pneumonia in China, 2019. N Engl J Med 2020; 382(8): 727-33.

4. Phelan AL, Katz R, Gostin LO. The Novel Coronavirus Originating in Wuhan, China: Challenges for Global Health Governance. JAMA 2020.

5. Rice TW, Rubinson L, Uyeki TM, et al. Critical illness from 2009 pandemic influenza A virus and bacterial coinfection in the United States. Crit Care Med 2012; 40(5): 1487-98.

6. McCullers JA. The co-pathogenesis of influenza viruses with bacteria in the lung. Nat Rev Microbiol 2014; 12(4): 252-62.

7. Rawson TM, Moore LSP, Zhu N, et al. Bacterial and fungal co-infection in individuals with coronavirus: A rapid review to support COVID-19 antimicrobial prescribing. Clin Infect Dis 2020.

8. Richardson S, Hirsch JS, Narasimhan M, et al. Presenting Characteristics, Comorbidities, and Outcomes Among 5700 Patients Hospitalized With COVID-19 in the New York City Area. Jama 2020.

9. Mercuro NJ, Yen CF, Shim DJ, et al. Risk of QT Interval Prolongation Associated With Use of Hydroxychloroquine With or Without Concomitant Azithromycin Among Hospitalized Patients Testing Positive for Coronavirus Disease 2019 (COVID-19). JAMA Cardiol 2020.

10. Crotty MP, Meyers S, Hampton N, et al. Epidemiology, Co-Infections, and Outcomes of Viral Pneumonia in Adults: An Observational Cohort Study. Medicine (Baltimore) 2015; 94(50): e2332.

11. Arashiro T, Nakamura S, Asami T, et al. SARS-CoV-2 and Legionella Co-infection in a Person Returning from a Nile Cruise. J Travel Med 2020. 
medRxiv preprint doi: https://doi.org/10.1101/2020.05.29.20117176; this version posted June 2, 2020. The copyright holder for this preprint

(which was not certified by peer review) is the author/funder, who has granted medRxiv a license to display the preprint in perpetuity.

It is made available under a CC-BY-NC-ND 4.0 International license .

12. Azekawa S, Namkoong H, Mitamura K, Kawaoka Y, Saito F. Co-infection with SARSCoV-2 and influenza A virus. IDCases Vol. 20. Netherlands: (c) 2020 The Author(s). 2020:e0775.

13. Chaung J, Chan D, Pada S, Tambyah PA. Coinfection with COVID-19 and Coronavirus HKU1 - the critical need for repeat testing if clinically indicated. J Med Virol 2020.

14. Khodamoradi Z, Moghadami M, Lotfi M. Co-infection of Coronavirus Disease 2019 and Influenza A: A Report from Iran. Arch Iran Med 2020; 23(4): 239-43.

15. Kim D, Quinn J, Pinsky B, Shah NH, Brown I. Rates of Co-infection Between SARSCoV-2 and Other Respiratory Pathogens. JAMA 2020.

16. Lin D, Liu L, Zhang M, et al. Co-infections of SARS-CoV-2 with multiple common respiratory pathogens in infected patients. Sci China Life Sci Vol. 63. China, 2020:606-9.

17. Nowak MD, Sordillo EM, Gitman MR, Paniz Mondolfi AE. Co-infection in SARS-CoV2 infected Patients: Where Are Influenza Virus and Rhinovirus/Enterovirus? J Med Virol 2020.

18. Ou X, Zhou L, Huang H, Lin Y, Pan X, Chen D. A severe case with co-infection of SARS-CoV-2 and common respiratory pathogens. Travel Med Infect Dis 2020: 101672.

19. Rodriguez JA, Rubio-Gomez H, Roa AA, Miller N, Eckardt PA. Co-Infection with SARS-COV-2 and Parainfluenza in a young adult patient with pneumonia: Case Report. IDCases Vol. 20. Netherlands: (c) 2020 The Author(s). 2020:e00762.

20. Touzard-Romo F, Tape C, Lonks JR. Co-infection with SARS-CoV-2 and Human Metapneumovirus. R I Med J (2013) 2020; 103(2): 75-6.

21. Wu X, Cai Y, Huang X, et al. Co-infection with SARS-CoV-2 and Influenza A Virus in Patient with Pneumonia, China. Emerg Infect Dis 2020; 26(6).

22. Klein EY, Monteforte B, Gupta A, et al. The frequency of influenza and bacterial coinfection: a systematic review and meta-analysis. Influenza Other Respir Viruses 2016; 10(5): 394-403.

23. Cauley LS, Vella AT. Why is coinfection with influenza virus and bacteria so difficult to control? Discov Med 2015; 19(102): 33-40.

24. Smith AM, McCullers JA. Secondary bacterial infections in influenza virus infection pathogenesis. Curr Top Microbiol Immunol 2014; 385: 327-56.

25. Kamat IS, Ramachandran V, Eswaran H, Guffey D, Musher DM. Procalcitonin to Distinguish Viral From Bacterial Pneumonia: A Systematic Review and Meta-analysis. Clin Infect Dis 2020; 70(3): 538-42.

26. Self WH, Balk RA, Grijalva CG, et al. Procalcitonin as a Marker of Etiology in Adults Hospitalized With Community-Acquired Pneumonia. Clin Infect Dis 2017; 65(2): 18390.

27. Musher DM, Roig IL, Cazares G, Stager CE, Logan N, Safar H. Can an etiologic agent be identified in adults who are hospitalized for community-acquired pneumonia: results of a one-year study. J Infect 2013; 67(1): 11-8.

28. Schimmel JJ, Haessler S, Imrey P, et al. Pneumococcal urinary antigen testing in US hospitals: A missed opportunity for antimicrobial stewardship. Clin Infect Dis 2019.

29. Musher DM, Jesudasen S, Barwatt JW, Cohen DN, Rodriguez-Barradas MC. The Etiology of Community-Acquired Pneumonia with Attention to the Role of Normal Respiratory Flora. Open Forum Infect Dis 2019; 6(Suppl 2): S749.

30. Dickson RP, Erb-Downward JR, Martinez FJ, Huffnagle GB. The Microbiome and the Respiratory Tract. Annu Rev Physiol 2016; 78: 481-504. 
medRxiv preprint doi: https://doi.org/10.1101/2020.05.29.20117176; this version posted June 2, 2020. The copyright holder for this preprint

(which was not certified by peer review) is the author/funder, who has granted medRxiv a license to display the preprint in perpetuity.

It is made available under a CC-BY-NC-ND 4.0 International license .

31. Faner R, Sibila O, Agusti A, et al. The microbiome in respiratory medicine: current challenges and future perspectives. Eur Respir J 2017; 49(4).

32. Dickson RP, Erb-Downward JR, Huffnagle GB. Towards an ecology of the lung: new conceptual models of pulmonary microbiology and pneumonia pathogenesis. Lancet Respir Med 2014; 2(3): 238-46. 
medRxiv preprint doi: https://doi.org/10.1101/2020.05.29.20117176; this version posted June 2, 2020. The copyright holder for this preprint (which was not certified by peer review) is the author/funder, who has granted medRxiv a license to display the preprint in perpetuity.

It is made available under a CC-BY-NC-ND 4.0 International license .

Table 1. Characteristics, Laboratory Findings, Treatments, and Clinical Outcomes of 289 Hospitalized Patients with COVID-19

\begin{tabular}{|c|c|c|c|c|}
\hline & $\begin{array}{l}\text { Total } \\
(n=289)\end{array}$ & $\begin{array}{l}\text { Bacte rial Respiratory } \\
\text { Co-Infection }(n=25)\end{array}$ & $\begin{array}{l}\text { No Respiratory Co- } \\
\text { Infection }(n=264)\end{array}$ & $\begin{array}{l}P \\
\text { value }\end{array}$ \\
\hline Age, years & $\begin{array}{l}58.6+/- \\
14.4\end{array}$ & $59.1+/-15.9$ & $58.5+/-14.3$ & \\
\hline \multicolumn{5}{|l|}{ Race/Ethnicity } \\
\hline African American & $139(48.3)$ & $7(28)$ & $132(50)$ & \\
\hline Hispanic & $68(23.5)$ & $8(32)$ & $60(22.7)$ & \\
\hline Caucasian & $61(21.1)$ & $7(28)$ & $54(20.5)$ & \\
\hline Other & $21(7.3)$ & $3(12)$ & $18(6.8)$ & \\
\hline \multicolumn{5}{|l|}{ Imaging } \\
\hline $\begin{array}{l}\text { Imaging showing } \\
\text { pneumonia, } \mathrm{n}(\%)\end{array}$ & $\begin{array}{c}242 / 281 \\
(86.1)\end{array}$ & $23(92.0)$ & $219(83.0)$ & \\
\hline Chest radiograph & $\begin{array}{c}218 / 275 \\
(79.3)\end{array}$ & $22(88.0)$ & $196(74.2)$ & \\
\hline CT & $\begin{array}{c}115 / 131 \\
(87.8)\end{array}$ & $16(64.0)$ & $99(37.5)$ & \\
\hline \multicolumn{5}{|l|}{ Comorbidities } \\
\hline Asthma & $26(9.0)$ & $3(12.0)$ & $23(8.7)$ & \\
\hline Chronic Heart Failure & $19(6.6)$ & $1(4.0)$ & $18(6.8)$ & \\
\hline $\begin{array}{l}\text { Chronic Obstructive } \\
\text { Pulmonary Disease }\end{array}$ & $18(6.2)$ & $2(8.0)$ & $16(6.1)$ & \\
\hline Chronic Kidney Disease & $21(7.3)$ & $0(0)$ & $21(8.0)$ & \\
\hline Cirrhosis & $3(1.0)$ & $0(0)$ & $3(1.1)$ & \\
\hline Coronary artery disease & $35(12.1)$ & $3(12.0)$ & $32(12.1)$ & \\
\hline Diabetes & $134(46.4)$ & $13(52.0)$ & $121(45.9)$ & \\
\hline Hypertension & $178(61.6)$ & $16(64.0)$ & $162(61.4)$ & \\
\hline End-stage renal disease & $18(6.2)$ & $2(8.0)$ & $16(6.1)$ & \\
\hline $\begin{array}{l}\text { Human Immunodeficiency } \\
\text { Virus }\end{array}$ & $7(2.4)$ & $0(0)$ & $7(2.7)$ & \\
\hline Malignancy & $20(6.9)$ & $0(0)$ & $20(7.6)$ & \\
\hline Sleep apnea & $5(1.7)$ & $1(4.0)$ & $4(1.5)$ & \\
\hline Transplant & $3(1.0)$ & $0(0)$ & $3(1.1)$ & \\
\hline No PMH & $53(18.3)$ & $3(12.0)$ & $50(18.9)$ & \\
\hline \multicolumn{5}{|c|}{ Laboratory Values on Admis sion } \\
\hline $\mathrm{WBC}\left(\mathrm{x} 10^{9} / \mathrm{L}\right)$ & $\begin{array}{l}7.1(5.1 \\
9.6)\end{array}$ & $10.1(6.5,12.5)$ & $7.0(4.9,9.3)$ & 0.002 \\
\hline $\begin{array}{l}\text { Absolute Lymphocytes } \\
\left(\times 10^{9} / \mathrm{L}\right)\end{array}$ & $\begin{array}{c}1.0(0.7 \\
1.4)\end{array}$ & $1.1(0.5,1.4)$ & $1.0(0.7,1.4)$ & 0.617 \\
\hline $\begin{array}{l}\text { Lactate Dehydrogenase } \\
\text { (U/L) }\end{array}$ & $\begin{array}{l}846(603 \\
1210)\end{array}$ & $1210(755,1451)$ & $834(589,1167)$ & 0.008 \\
\hline Ferritin $(\mathrm{ng} / \mathrm{mL})$ & $\begin{array}{l}411(192 \\
908)\end{array}$ & $510(368,901)$ & $372(182,916)$ & 0.267 \\
\hline $\begin{array}{l}\text { C-Reactive Protein } \\
(\mathrm{mg} / \mathrm{dL})\end{array}$ & $\begin{array}{l}76(39, \\
189)\end{array}$ & $182(58,266)$ & $74(38,181)$ & 0.013 \\
\hline Procalcitonin (ng/mL) & $\begin{array}{l}0.16(0.08 \\
0.42)\end{array}$ & $0.37(0.19,1.53)$ & $0.07(0.15,0.38)$ & 0.001 \\
\hline
\end{tabular}




\begin{tabular}{|c|c|c|c|c|}
\hline Procalcitonin $>0.25$ & $95(32.9)$ & $17(68.0)$ & $78(29.5)$ & $<.001$ \\
\hline Procalcitonin $>0.5$ & $54(18.7)$ & $10(40.0)$ & $44(16.7)$ & 0.004 \\
\hline Interleukin-6 (pg/mL) & $11(<5,37)$ & $48(10,71)$ & $10(5,21)$ & 0.011 \\
\hline D-Dimer (ng/mL) & $\begin{array}{c}1.16(0.71, \\
2.35)\end{array}$ & $1.51(0.96,3.87)$ & $1.13(0.66,2.25)$ & 0.114 \\
\hline \multicolumn{5}{|l|}{ Treatments } \\
\hline Antibiotic & $271(93.8)$ & $25(100)$ & $246(93.2)$ & 0.381 \\
\hline Hydroxychloroquine & $163(56.4)$ & $18(72)$ & $145(54.9)$ & 0.151 \\
\hline Remdesivir & $28(9.7)$ & $0(0)$ & $28(10.6)$ & $<0.001$ \\
\hline Steroids & $70(24.2)$ & $12(48.0)$ & $58(22.0)$ & 0.004 \\
\hline Tocilizumab & $18(6.2)$ & $5(20.0)$ & $13(4.9)$ & 0.013 \\
\hline \multicolumn{5}{|l|}{ Clinical Outcomes* } \\
\hline Length-of-stay & $7(4,11)$ & $10(5,16)$ & $7(4,11)$ & 0.124 \\
\hline ICU admission & $105(36.3)$ & $21(84.0)$ & $84(31.8)$ & $<.001$ \\
\hline ICU Length-of-stay & $\begin{array}{l}7.5(4, \\
16.5)\end{array}$ & $8.5(5,12)$ & $7(3,17)$ & 0.805 \\
\hline Mechanical ventilation & $81(28.0)$ & $18(72.0)$ & $63(23.9)$ & $<.001$ \\
\hline $\begin{array}{l}\text { Mechanical ventilation } \\
\text { duration, days }\end{array}$ & $9(5,14)$ & $6.5(5,12)$ & $9.5(5,15)$ & 0.253 \\
\hline In-hospital mortality & $33(11.4)$ & $9(45.0)$ & $24(9.8)$ & $<.001$ \\
\hline
\end{tabular}

Age is presented as mean +/- SD. Other continuous variables are presented as median (IQR) and compared with Mann-Whitney U test. Categorical variables are shown as number (\%). Chisquared or Fisher's exact tests were used to compare categorical variables between groups.

*Information not available or incomplete for patients remaining admitted 
medRxiv preprint doi: https://doi.org/10.1101/2020.05.29.20117176; this version posted June 2, 2020. The copyright holder for this preprint (which was not certified by peer review) is the author/funder, who has granted medRxiv a license to display the preprint in perpetuity. It is made available under a CC-BY-NC-ND 4.0 International license .

Table 2. Microbiologic Diagnostic Evaluation, by Bacterial Respiratory Co-Infection Status

\begin{tabular}{|l|c|c|c|}
\hline \multicolumn{1}{|c|}{$\mathbf{n}(\boldsymbol{\%})$} & Total (n=289) & $\begin{array}{c}\text { Bacterial Respiratory } \\
\text { Co-Infection (n=25) }\end{array}$ & $\begin{array}{c}\text { No Bacterial } \\
\text { Respiratory Co- } \\
\text { Infection (n=264) }\end{array}$ \\
\hline Blood Cultures & $242(83.7)$ & $25(100)$ & $217(82.2)$ \\
\hline Flu (Any) & $214(74.0)$ & $24(96.0)$ & $190(72.0)$ \\
\hline \multicolumn{1}{|c|}{ Flu Screen } & $182(63.0)$ & $22(88.0)$ & $160(60.6)$ \\
\hline Flu PCR & $198(68.5)$ & $24(96.0)$ & $174(65.9)$ \\
\hline Strep pneumo Ur Ag & $159(55.0)$ & $20(80.0)$ & $139(52.7)$ \\
\hline Legionella Ur Ag & $28(9.7)$ & $3(12.0)$ & $173(65.5)$ \\
\hline RVP & $197(68.2)$ & $24(96.0)$ & $59(22.3)$ \\
\hline MRSA nasal screen & $71(24.6)$ & $12(48.0)$ & $39(14.8)$ \\
\hline $\begin{array}{l}\text { Respiratory Culture } \\
\text { (Any) }\end{array}$ & $55(19.0)$ & $16(64.0)$ & $30(11.4)$ \\
\hline \multicolumn{1}{|c|}{ Tracheal aspirate } & $42(14.5)$ & $12(48.0)$ & $4(1.5)$ \\
\hline Bronchoscopy & $4(1.4)$ & $0(0)$ & $30(11.4)$ \\
\hline \multicolumn{1}{|c|}{ Sputum } & $16(5.5)$ & $5(20.0)$ & \\
\hline CDI Testing & $32(11.1)$ & $2(8.0)$ & \\
\hline
\end{tabular}


Table 3. Pathogens Identified, by Infection Type

\begin{tabular}{|c|c|c|}
\hline Infection Type & Pathogen & $\mathbf{N}$ \\
\hline \multicolumn{3}{|l|}{ Respiratory Co-Infection $(n=31)$} \\
\hline Bacterial $(n=25)$ & Bordetella holmesii & 1 \\
\hline & Staphylococcus aureus & 5 \\
\hline & Streptococcus pneumoniae & 3 \\
\hline & Group A Streptococci & 1 \\
\hline & Oral Bacterial Flora & 15 \\
\hline Virus $(n=6)$ & Adenovirus & 1 \\
\hline & Influenza $\mathrm{A}$ & 1 \\
\hline & Influenza $\mathrm{B}$ & 1 \\
\hline & Metapneumovirus & 1 \\
\hline & Rhinovirus & 2 \\
\hline \multicolumn{3}{|c|}{ Subsequent Respiratory Infection $(n=11)$} \\
\hline Bacterial $(n=10)$ & Staphylococcus aureus & 2 \\
\hline & Streptococcus pneumoniae & 1 \\
\hline & Pseudomonas aeruginosa & 3 \\
\hline & Klebsiella spp. & 2 \\
\hline & E. coli & 1 \\
\hline & Stenotrophomonas maltophila & 1 \\
\hline Fungal $(n=1)$ & Aspergillus niger & 1 \\
\hline \multicolumn{3}{|l|}{ Other Subsequent Infections $(n=7)$} \\
\hline $\begin{array}{l}\text { Bloodstream } \\
(n=3)\end{array}$ & Staphylococcus epidermidis & 1 \\
\hline & Candida sp. & 2 \\
\hline $\begin{array}{l}\text { Urinary Tract } \\
(\mathrm{n}=1)\end{array}$ & Group B Streptococci & 1 \\
\hline Other $(n=3)$ & C. difficile & 3 \\
\hline
\end{tabular}

*Patient could have more than one pathogen or infection 
Table 4. Variables retained in Cox Proportional Hazards Model for In-Patient Mortality

\begin{tabular}{|l|l|c|}
\hline \multicolumn{1}{|c|}{ Covariate } & \multicolumn{1}{c|}{ aHR (95\% CI) } & $\boldsymbol{P}$ value \\
\hline Age, years & $1.044(1.011-1.079)$ & 0.009 \\
\hline ICU admission & $6.341(1.498-26.851)$ & 0.012 \\
\hline Mechanical ventilation & $1.146(0.373-3.524)$ & 0.812 \\
\hline COPD & $1.218(0.473-3.137)$ & 0.683 \\
\hline CAD & $1.151(0.416-3.184)$ & 0.786 \\
\hline CKD & $1.415(0.469-4.266)$ & 0.538 \\
\hline Cirrhosis & $5.912(1.104-31.669)$ & 0.038 \\
\hline Bacterial respiratory co-infection & $3.368(1.391-8.155)$ & 0.007 \\
\hline Steroids & $0.333(0.142-0.783)$ & 0.012 \\
\hline
\end{tabular}

Abbreviations: CAD, coronary artery disease; CKD, Chronic kidney diseases; COPD, Chronic obstructive pulmonary disease; 
medRxiv preprint doi: https://doi.org/10.1101/2020.05.29.20117176; this version posted June 2, 2020. The copyright holder for this preprint (which was not certified by peer review) is the author/funder, who has granted medRxiv a license to display the preprint in perpetuity.

Figure 1. Flow Diagram of Patient Identification and Classification

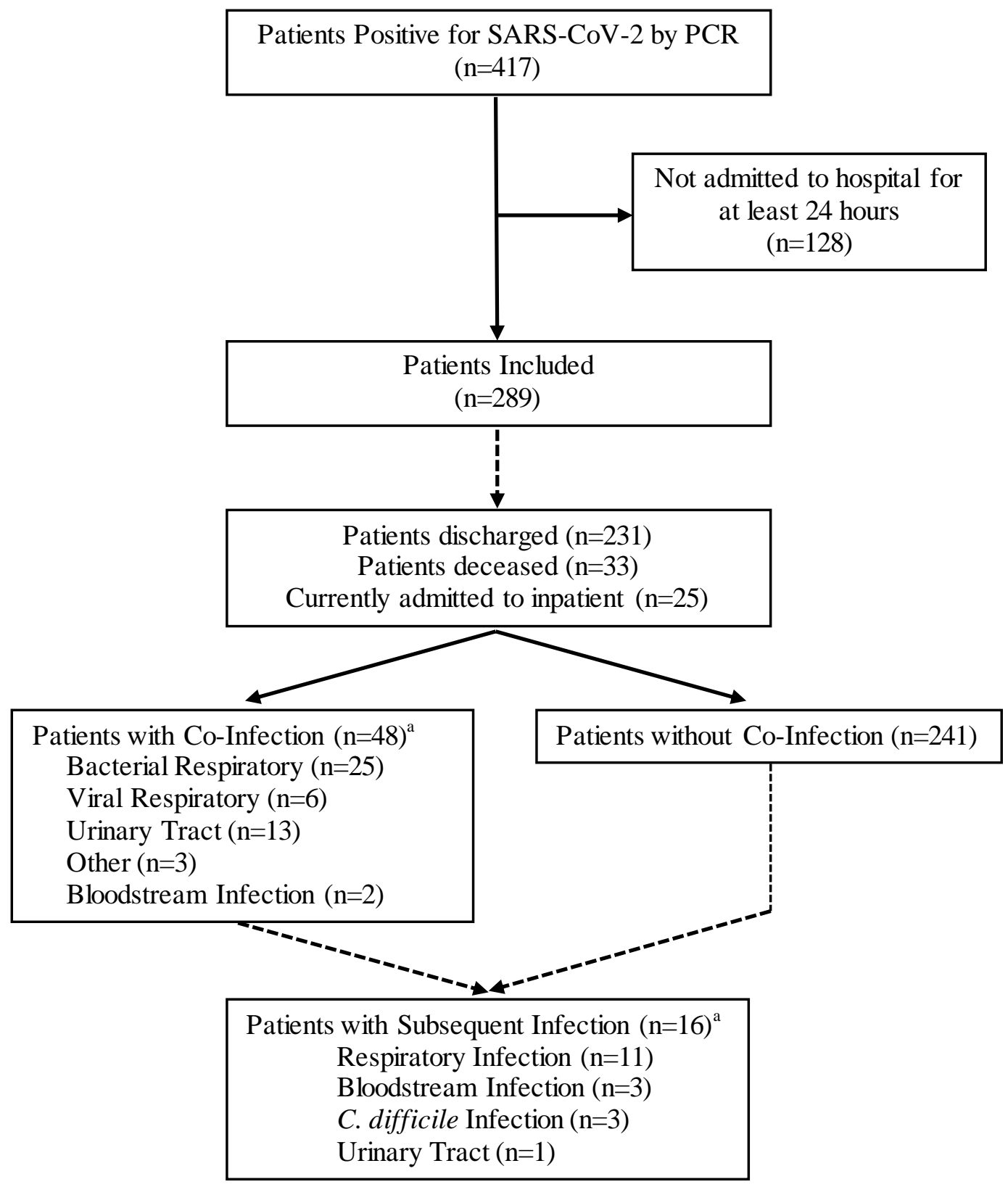

${ }^{\text {a }}$ Patients could have more than one co-infection or subsequent infection 
Figure 2. Model-Adjusted Estimated In-Hospital Mortality, by Bacterial Respiratory CoInfection Status

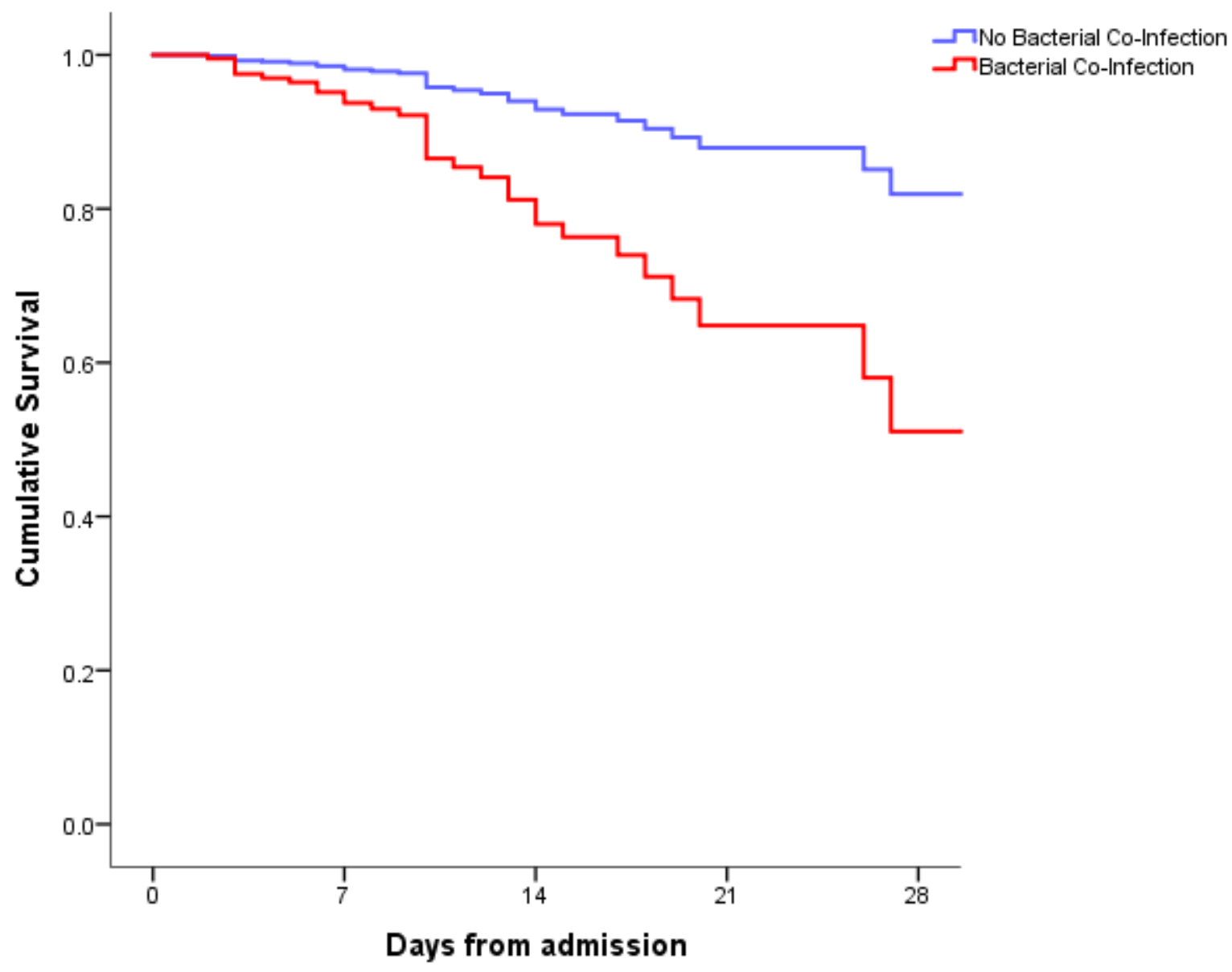

Graph is based on a Cox proportional hazards model. Compared with the no bacterial infection group, the group with a bacterial respiratory co-infection had a statistically lower rate of survival, at $\alpha=.05: \mathrm{P}=.007$. 